\title{
$\left[{ }^{3} \mathrm{H}\right]-Q U I N U C L I D I N Y L$ BENZILATE BINDING TO MUSCARINIC RECEPTORS IN RAT BRAIN: COMPARISON OF RESULTS FROM INTACT BRAIN SLICES AND HOMOGENATES
}

\author{
R.F.T. GILBERT, M.R. HANLEY \& L.L. IVERSEN
}

MRC Neurochemical Pharmacology Unit, Dept. of Pharmacology, Medical School, Hills Road, Cambridge

1 The binding of $\left[{ }^{3} \mathrm{H}\right]-( \pm)$-quinuclidinyl benzilate $\left(\left[{ }^{3} \mathrm{H}\right]-( \pm)-\mathrm{QNB}\right)$ to muscarinic sites in rat brain slice and homogenate preparations was compared.

2 Evidence is presented in support of the view that only the (-)-enantiomer of QNB binds with high affinity to muscarinic sites.

3 The $K_{d}$ value for $\left[{ }^{3} \mathrm{H}\right]-(-)-Q N B$ binding in slices was eight times higher than that measured in homogenates.

4 Similarly, the potencies of various muscarinic ligands as inhibitors of $\left[{ }^{3} \mathrm{H}\right]-(-)-\mathrm{QNB}$ binding were consistently lower in slices than in homogenates.

5 It is proposed that the results may reflect differences in the binding properties of muscarinic receptors in intact tissue slice and homogenate preparations.

\section{Introduction}

$\left[{ }^{3} \mathrm{H}\right]$-quinuclidinyl benzilate $(\mathrm{QNB})$ has been widely used as a specific ligand for muscarinic acetylcholine receptors in CNS and in peripheral tissues (Yamamura \& Snyder, 1974a, b; Strange, Birdsall \& Burgen, 1978). Hitherto, most studies with this ligand have involved the use of cell-free membrane fragment preparations, obtained by vigorous homogenization of brain or peripheral tissue, although Yamamura, Kuhar \& Snyder (1974) showed that $\left[{ }^{3} \mathrm{H}\right]-\mathrm{QNB}$ could be used to label muscarinic receptors in the intact rat brain after systemic administration in vivo. Recent results with another muscarinic ligand, $\left[{ }^{3} \mathrm{H}\right]$-propylbenzilylcholine mustard (Burgen, Hiley \& Young, 1974), show that the binding characteristics measured in intact intestinal muscle strips differ significantly from those measured in cell-free homogenates (Ward \& Young, 1977). In the present study we have explored the possibility of measuring specific binding of $\left[{ }^{3} \mathrm{H}\right]-\mathrm{QNB}$ to muscarinic sites in slices of intact rat brain, and have compared these results with data obtained from cell-free homogenates of the same tissue.

The rat corpus striatum and hippocampus were chosen since they contain relatively high densities of muscarinic binding sites (Yamamura \& Snyder, 1974a). Since QNB is optically active, and it is known that the (-)-enantiomer is considerably more potent as an antimuscarinic agent than the $(+)$-enantiomer (Meyerhoffer, 1972), we have also taken into account the stereoselectivity of the interaction of $\left[{ }^{3} \mathrm{H}\right]-( \pm)-$
QNB with CNS binding sites. Our results indicate that only the (-)-enantiomer of the labelled drug contributes significantly to the observed binding, and confirm that there are significant differences in the binding characteristics observed in slices versus brain homogenates.

\section{Methods}

\section{$\left[{ }^{3} \mathrm{H}\right]-Q N B$ binding to rat brain homogenates}

These experiments were performed essentially as described by Yamamura \& Snyder (1974a). Male Wistar rats (100 to $200 \mathrm{~g}$ ) were decapitated, and their brains rapidly removed and chilled. Corpus striatum and hippocampus were dissected (Glowinski \& Iversen, 1966) and homogenized in $10 \mathrm{vol}(\mathrm{w} / \mathrm{v})$ of ice-cold $0.32 \mathrm{M}$ sucrose in a Potter-Elvehjem glass homogenizer fitted with a Teflon pestle. The homogenate was centrifuged for $10 \mathrm{~min}$ at $1000 \mathrm{~g}$. The pellet (crude nuclear fraction) was discarded, and the supernatant diluted 40 to 120 fold with $0.05 \mathrm{M}$ sodium-potassium phosphate buffer $\mathrm{pH}$ 7.4, or with Krebs-bicarbonate solution $\mathrm{pH}$ 7.4. The diluted homogenate was further homogenized with a Polytron (setting No. 5, $60 \mathrm{~s}$ ), and used for $\left[{ }^{3} \mathrm{H}\right]-\mathrm{QNB}$ binding studies.

Samples of diluted homogenate $(2 \mathrm{ml})$ were incubated at $25^{\circ} \mathrm{C}$ for $60 \mathrm{~min}$ with various concentrations of $\left[{ }^{3} \mathrm{H}\right]-\mathrm{QNB}$. At the end of the incubation, $3 \mathrm{ml}$ of ice-cold 0.05 м Na-K phosphate buffer $\mathrm{pH} 7.4$, or 
Krebs-bicarbonate solution was added, and the samples passed through a glass fibre filter (Whatman GF/B) under vacuum. The filters were washed twice under vacuum with $3 \mathrm{ml}$ of ice-cold buffer. Each determination of binding was performed in triplicate, together with triplicate samples containing $1 \mu \mathrm{M}$ atropine to estimate non-specific binding.

Each filter was placed in a scintillation vial, $4 \mathrm{ml}$ of ethoxyethanol added and the vial sealed and left overnight. Then $10 \mathrm{ml}$ of $0.4 \%$ butyl-PBD in toluene was added, and the radioactivity counted by liquid scintillation spectrometry.

\section{$\left[{ }^{3} H\right]-Q N B$ binding to brain slices}

The method used was a modification of that described by Hanley \& Iversen (1978). Striatal or hippocampal tissue was cross chopped at $250 \mu \mathrm{m}$ intervals with a McIlwain tissue chopper. The slices (80 to $100 \mathrm{mg}$ wet weight from one rat brain) were incubated at $37^{\circ} \mathrm{C}$ in $50 \mathrm{ml} \mathrm{Krebs-bicarbonate} \mathrm{solution} \mathrm{pH} 7.4$ for 20 to 30 minutes. The supernatant was then decanted and the tissue concentration adjusted to $200 \mathrm{mg} / \mathrm{ml}$. Twenty-five $\mu \mathrm{l}$ of the suspension ( $5 \mathrm{mg}$ tissue) was added to a $25 \mathrm{ml}$ conical flask containing $4 \mathrm{ml}$ Krebsbicarbonate solution and $25 \mu \mathrm{l}$ of $\left[{ }^{3} \mathrm{H}\right]-\mathrm{Q} N B$ solution was added. For each concentration of $\left[{ }^{3} \mathrm{H}\right]-\mathrm{QNB}$, triplicate determinations of binding were made, and also triplicate determinations of non-specific binding in the presence of $1 \mu \mathrm{M}$ atropine. The flasks were incubated at $37^{\circ} \mathrm{C}$ with continuous shaking for $30 \mathrm{~min}$ utes. At the end of the incubation, the contents of the flasks were filtered rapidly through $25 \mathrm{~mm}$ diameter glass fibre filters (Whatman GF/B) under vacuum. The flasks were rinsed with $4 \mathrm{ml}$ Krebsbicarbonate solution which was passed through the filters. The tissue slices and filters were washed rapidly with $2 \times 4 \mathrm{ml}$ Krebs-bicarbonate solution under vacuum. The filters were prepared for liquid scintillation counting as described for homogenate binding experiments.

\section{Inhibition of $\left[{ }^{3} \mathrm{H}\right]-\mathrm{QNB}$ binding by muscarinic drugs}

In order to compare the inhibition of specific $\left[{ }^{3} \mathrm{H}\right]-\mathrm{QNB}$ binding by muscarinic drugs in striatal slices and homogenates, various concentrations of each drug were included in the incubation media (Krebs-bicarbonate solution in each case), together with a fixed concentration of $1.5 \mathrm{nM}\left[{ }^{3} \mathrm{H}\right]-( \pm)-\mathrm{QNB}$.

Each drug was tested at 4 to 8 different concentrations, and each concentration was tested on triplicate samples. $\mathrm{IC}_{50}$ values were estimated from $\mathrm{log} /$ probit analysis of dose-response curves relating percentage inhibition of specific $\left[{ }^{3} \mathrm{H}\right]-\mathrm{QNB}$ binding to drug concentration and the mean values determined from 3 to 5 separate experiments were used to calculate values for the apparent inhibition constant $\left(K_{\mathrm{i}}\right)$ presented in Table 2. Apparent $K_{\mathrm{i}}$ values were calculated from the formula:-

$$
K_{\mathrm{i}}=\left(\mathrm{IC}_{50}\right) /\left(1+\mathrm{S} / K_{\mathrm{d}}\right)
$$

where $\mathrm{S}=$ concentration of $\left[{ }^{3} \mathrm{H}\right]-(-)-\mathrm{QNB}=0.75$ nM.

$\left[{ }^{3} \mathrm{H}\right]-( \pm)-Q N B(13 \mathrm{Ci} / \mathrm{mmol})$ was obtained in ethanol solution from the Radiochemical Centre, Amersham. $\left[{ }^{3} \mathrm{H}\right]-\mathrm{QNB}$ moved as a single peak with authentic QNB in high voltage electrophoresis $(100 \mathrm{~V} / \mathrm{cm}$; citric acid/phosphate buffer, $\mathrm{pH}$ 3.0). Other drugs were obtained as follows: oxotremorine sesquifumarate from Aldrich Chemical Co. Inc; arecoline hydrobromide, pilocarpine hydrochloride, carbamylcholine hydrochloride (carbachol) and atropine sulphate from Sigma Chemical Co.

\section{Results}

\section{Stereoselectivity of $\left[{ }^{3} \mathrm{H}\right]-Q N B$ binding}

It has been reported that only the (-)-isomer of (+)-QNB possesses significant antimuscarinic activity in vivo (Meyerhoffer, 1972). This has been confirmed in binding studies (Kloog \& Sokolovsky, 1977) in which (-)-QNB was found to be approximately 100 times more potent than $(+)-\mathrm{QNB}$ in displacing the specific binding of $\left[{ }^{3} \mathrm{H}\right]-\mathrm{N}$-methyl-4-piperidylbenzilate to muscarinic sites in brain homogenates. It seems likely, therefore, that when $\left[{ }^{3} \mathrm{H}\right]-( \pm)-Q N B$ is used to label muscarinic sites only the $(-)$-isomer is involved. This hypothesis was supported by the finding that a maximum of approximately $50 \%$ of the total $\left[{ }^{3} \mathrm{H}\right]-( \pm)-Q N B$ added was specifically bound when incubations were performed with $0.2 \mathrm{~nm}$ $\left[{ }^{3} \mathrm{H}\right]-\mathrm{QNB}$ and various concentrations of striatal tissue homogenate (Figure 1). In calculations of the constants for $\left[{ }^{3} \mathrm{H}\right]-\mathrm{QNB}$ binding to slices and homogenates we have, therefore, assumed that only the active (-)-isomer is involved. This is an important consideration in estimating free ligand concentrations, since under some circumstances when low concentrations of $\left[{ }^{3} \mathrm{H}\right]-( \pm)-\mathrm{QNB}$ are used, a high proportion of the active $(-)$-isomer may be specifically bound, although the inactive $(+)$-isomer remains free. We have also assumed that non-specific binding is not stereospecific. However, even if non-specific binding involved only $\left[{ }^{3} \mathrm{H}\right]-(-)-Q N B$, this would not materially alter our calculations since the amount of non-specific binding in both slice and homogenate experiments was never greater than $10 \%$ of the amount of $\left[{ }^{3} \mathrm{H}\right]-(-)-\mathrm{QNB}$ present. 


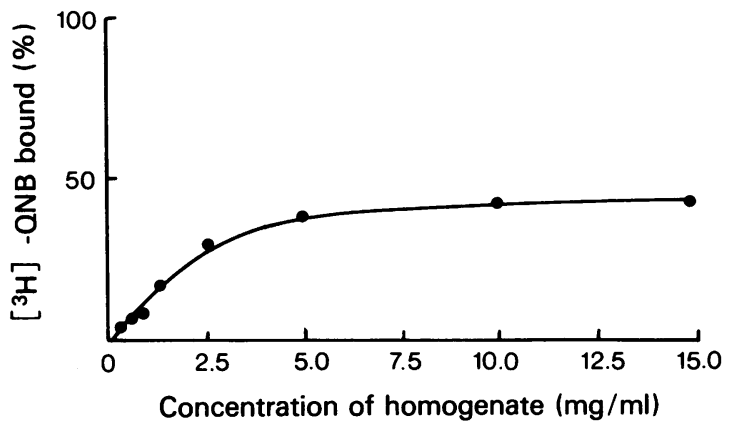

Figure 1 Specific binding of $\left[{ }^{3} \mathrm{H}\right]-( \pm)$-quinuclidinyl benzilate $\left(\left[{ }^{3} \mathrm{H}\right]-( \pm)-Q N B\right)$ as a function of tissue concentration; $\%$ of total label added $\left(0.2\right.$ nM $\left[{ }^{3} \mathrm{H}\right]$ $( \pm)-Q N B)$ bound against tissue concentration (striatal homogenate).

\section{$\left[{ }^{3} \mathrm{H}\right]-Q N B$ binding in homogenates}

As described previously (Yamamura \& Snyder, 1974a) specific binding of $\left[{ }^{3} \mathrm{H}\right]-\mathrm{QNB}$ in rat striatal and hippocampal homogenates incubated in phosphate buffer represented a major proportion of total binding (Figure 2). Specific binding, but not non-specific binding. was saturable, and Scatchard analysis indicated a $K_{\mathrm{d}}$ for (-)-QNB of $0.042 \mathrm{nM}$ in striatum and 0.025 nM in hippocampus (Table 1). If the same results were used to calculate apparent $K_{\mathrm{d}}$ values for $\left[{ }^{3} \mathrm{H}\right]-( \pm)$ QNB the values obtained were considerably higher ( $0.24 \mathrm{~nm}$ in striatum and $0.1 \mathrm{~nm}$ in hippocampus). The latter values are similar to the concentrations $(0.3$ to $0.5 \mathrm{nM})$ of $\left[{ }^{3} \mathrm{H}\right]-( \pm)-\mathrm{QNB}$ found to cause $50 \%$ saturation of specific binding sites in rat brain or guineapig ileum by Yamamura \& Snyder (1974a, b). Their estimates of the $K_{d}$ for QNB, however, based on measurements of rates of association and dissociation were 0.03 to $0.06 \mathrm{nM}$, values which are in close agreement with our estimates of $K_{d}$ for (-)-QNB from saturation analysis. This result is now explicable, since measurements of association and dissociation presumably reflect only the behaviour of the active (-)-isomer.

As reported by Yamamura \& Snyder (1974a) the density of specific QNB binding sites in striatal homogenates was approximately twice that observed in hippocampal homogenates, although the absolute values are higher than found by these authors (Table 1).

When tissue homogenates were incubated in Krebs bicarbonate solution instead of phosphate buffer, the maximum specific binding was unchanged, but the estimated $K_{\mathrm{d}}$ values for $(-)$-QNB were higher than those observed in phosphate buffer (Table 1), an effect which may be attributed to the difference in ionic strength of the two media (Birdsall, Burgen, Hulme \& Wells, 1977).
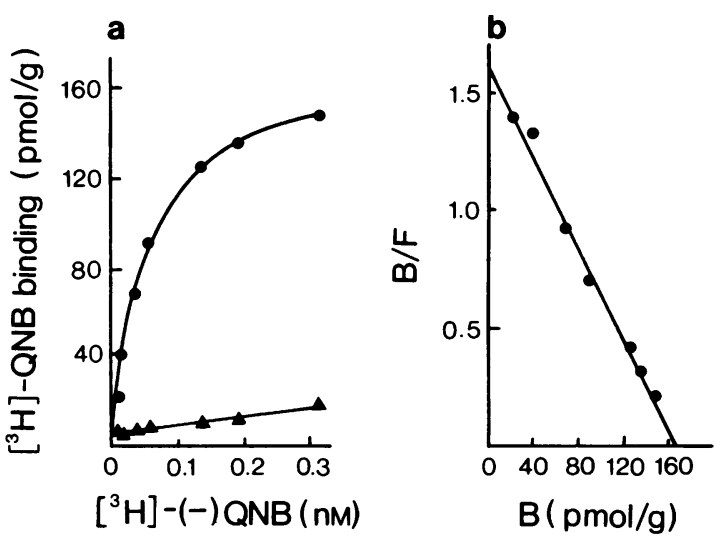

Figure 2 (a) Specific (O) and non-specific (A) components of $\left[{ }^{3} \mathrm{H}\right]-(-)$-quinuclidinyl benzilate $\left(\left[{ }^{3} \mathrm{H}\right]-(-)\right.$ QNB) binding to a homogenate of rat corpus striatum in $0.05 \mathrm{M} \mathrm{Na}-\mathrm{K}$ phosphate buffer. (b) Scatchard plot of specific binding data. Calculated $K_{\mathrm{d}}$ for $(-)$-QNB $=0.042 \mathrm{nM}$.

\section{$\left[{ }^{3} H\right]-Q N B$ binding in tissue slices}

The general characteristics of $\left[{ }^{3} \mathrm{H}\right]-\mathrm{QNB}$ binding to striatal slices have already been described in a previous publication (Hanley \& Iversen, 1978). Specific binding of $\left[{ }^{3} \mathrm{H}\right]-\mathrm{QNB}$ occurred rapidly, and reached saturation within $30 \mathrm{~min}$ at $37^{\circ} \mathrm{C}$. Non-specific binding accounted for a higher proportion of total binding than in homogenate experiments, and furthermore the amount of non-specific binding increased linearly with incubation time (Hanley \& Iversen, 1978). Specific binding, measured after a standard incubation of $30 \mathrm{~min}$ was at least as great as non-specific binding except at the highest ligand concentrations tested, and at low concentrations of $\left[{ }^{3} \mathrm{H}\right]-\mathrm{QNB}$ accounted for as much as $80 \%$ of total binding in striatal slices. Specific binding, but not non-specific binding was saturable (Figure 3 ) and the estimated $K d$ values for $(-)$-QNB were $0.52 \mathrm{~nm}$ for striatal tissue and $0.35 \mathrm{~nm}$ for hippocampal tissue (Table 1). These values are 7 to 9 times higher than those estimated for (-)-QNB binding in homogenates of these tissues (Table 1).

The maximum density of specific QNB binding sites in striatal slices was approximately 2.5 times higher than in hippocampal slices, and the absolute values estimated from slice binding experiments were similar to those estimated in homogenates (Table 1) when results were expressed per unit weight of brain tissue.

In brain slices, as in homogenates, the specific binding of $\left[{ }^{3} \mathrm{H}\right]-\mathrm{QNB}$ could be described by simple mass action kinetics, since Hill coefficients were close to 1.0 . 

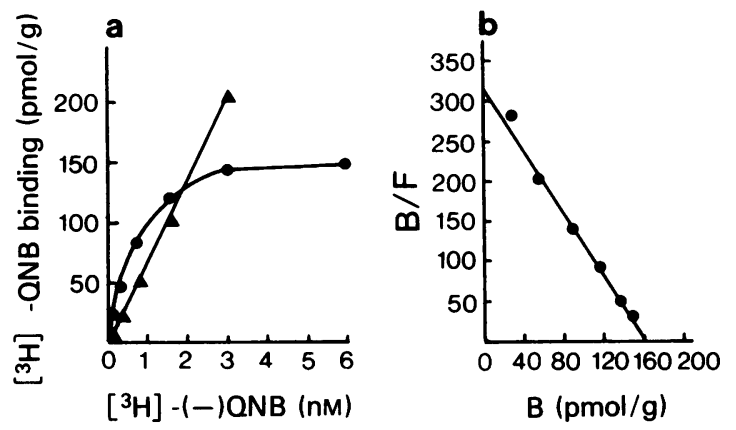

Figure 3 (a) Specific (๑) and non-specific ( $\Delta$ ) components of $\left[{ }^{3} \mathrm{H}\right]-(-)$-quinuclidinyl benzilate $\left(\left[{ }^{3} \mathrm{H}\right]-(-)\right.$ QNB) binding to slices of rat corpus striatum in Krebsbicarbonate solution. (b) Scatchard plot of specific binding data. Calculated $K_{\mathrm{c}}$ for $(-)-\mathrm{QNB}=0.52 \mathrm{nM}$.

\section{Inhibition of $\left[{ }^{3} \mathrm{H}\right]-Q N B$ binding in striatal slices and homogenates by muscarinic drugs}

Five drugs were tested in striatal slice and homogenate preparations for their ability to inhibit specific $\left[{ }^{3} \mathrm{H}\right]-\mathrm{QNB}$ binding. Each drug was tested at several concentrations and $\mathrm{IC}_{50}$ values were estimated from the dose-response curves and $K_{\mathrm{i}}$ values calculated as described in Methods. The calculated $K_{\mathrm{i}}$ values (Table 2) for both agonists and antagonists were consistently 5 to 10 times higher in slice experiments than in homogenates.

\section{Discussion}

The first experimental approach to ligand binding studies for muscarinic receptors was the now classic study of Paton \& Rang (1965) who measured the binding of $\left[{ }^{3} \mathrm{H}\right]$-atropine to intact strips of intestinal smooth muscle. Since then a variety of reversible and irreversible ligands have been used to identify and characterize muscarinic binding sites in peripheral tissues and in CNS (for review see Birdsall \& Hulme, 1976). In most cases such studies have been performed with tissue homogenates, although some recent studies have used intact preparations of intestinal smooth muscle (Burgen et al., 1974; Ward \& Young, 1977). In a previous publication (Hanley \& Iversen, 1978) we described the application of $\left[{ }^{3} \mathrm{H}\right]-\mathrm{QNB}$ binding to studies of muscarinic receptors in intact slices of corpus striatum from rat brain. In the present paper we describe a more detailed comparison of the properties of $\left[{ }^{3} \mathrm{H}\right]-\mathrm{QNB}$ binding in slices and homogenates of two regions of rat brain. In addition we have taken into consideration the stereoselectivity of QNB binding in estimates of its binding parameters. The finding that only approximately half of the added labelled ligand appears to be available for specific binding to striatal homogenates strongly supports the view that only the pharmacologically active (-)-isomer is involved in specific binding to muscarinic sites. This has an important influence on the kinetic constants calculated for saturable QNB binding, and may, for example, explain why previous estimates of $K_{d}$ values for $\left[{ }^{3} \mathrm{H}\right]-\mathrm{QNB}$ based on saturation analysis and by measurements of association and dissociation rate constants have shown only poor agreement (Yamamura \& Snyder, 1974a, b).

As described previously (Hanley \& Iversen, 1978), specific binding of $\left[{ }^{3} \mathrm{H}\right]-\mathrm{QNB}$ can be measured readily in intact slices of brain tissue incubated in vitro. This is not surprising, since specific binding of $\left[{ }^{3} \mathrm{H}\right]-\mathrm{QNB}$ to muscarinic sites in rat brain can be demonstrated even after administration of the labelled drug in vivo (Yamamura et al., 1974), and specific binding of $\left[{ }^{3} \mathrm{H}\right]$-propylbenzilylcholine mustard $\left(\left[{ }^{3} \mathrm{H}\right]-\operatorname{PrBCM}\right)$ to muscarinic sites in rat brain slices has been demonstrated autoradiographically (Rotter, Birdsall, Burgen, Field \& Raisman, 1977).

Table 1 Parameters for specific $\left[{ }^{3} \mathrm{H}\right]$-quinuclidinyl benzilate $\left(\left[{ }^{3} \mathrm{H}\right]\right.$-QNB) binding in rat brain slices and homogenates

Tissue and experimental conditions

Striatum

Homogenate-phosphate buffer

Homogenate-Krebs bicarbonate

Slices-Krebs bicarbonate

Hippocampus

Homogenate-phosphate buffer

Homogenate-Krebs bicarbonate

Slices-Krebs bicarbonate

$$
K_{\mathrm{d}}(\mathrm{nM})
$$

$$
\begin{gathered}
0.042 \pm 0.004(3) \\
0.060(2) \\
0.532 \pm 0.055(3)
\end{gathered}
$$

$$
\begin{aligned}
& 0.025(2) \\
& 0.050(1) \\
& 0.350(1)
\end{aligned}
$$

$B_{\max }$ (pmol/g wet wt.)

$$
\begin{gathered}
161.7 \pm 5.0(3) \\
142.7(2) \\
170.8 \pm 6.7(3) \\
\\
67.4(2) \\
77.2(1) \\
68.0(1)
\end{gathered}
$$

Values for dissociation constant $\left(K_{\mathrm{d}}\right)$ and maximum specific binding $\left(\mathbf{B}_{\mathrm{max}}\right)$ were derived from Scatchard analysis of saturation curves, as illustrated in Figures 2 and 3. Values are means \pm s.e. mean for the number of experimental determinations indicated in parentheses. 
Table 2 Comparison of inhibition of $\left[{ }^{3} \mathrm{H}\right]$-quinuclidinyl benzilate $\left(\left[{ }^{3} \mathrm{H}\right]-\mathrm{QNB}\right)$ binding in slices and homogenates of rat striatum by muscarinic drugs

\begin{tabular}{lccccc} 
& \multicolumn{4}{c}{ Calculated $K_{\mathrm{i}}$ value for inhibition } \\
of specific $\left[{ }^{3} \mathrm{H}\right]-Q N B$ binding $(\mathrm{nM})$ & \\
\multicolumn{1}{c}{ Drug } & $n$ & Slices & $n$ & Homogenates & Ratio $S / H$ \\
& & & & \\
Atropine & 5 & $3.47 \pm 0.62$ & 5 & $0.42 \pm 0.06$ & 8.3 \\
Scopolamine & 4 & $5.78 \pm 0.48$ & 3 & $0.95 \pm 0.13$ & 6.1 \\
$\begin{array}{l}\text { Oxotremorine } \\
\text { Arecoline }\end{array}$ & 3 & $8,780 \pm 2,380$ & 3 & $810 \pm 230$ & 10.8 \\
Carbachol & 4 & $119,600 \pm 55,600$ & 3 & $11,630 \pm 3,440$ & 10.3 \\
& 3 & $227,500 \pm 136,800$ & 4 & $43,570 \pm 2,420$ & 5.2
\end{tabular}

Drugs were tested for their ability to inhibit specific $\left[{ }^{3} \mathrm{H}\right]-\mathrm{QNB}$ binding in slices or homogenates of rat striatum incubated with $1.5 \mathrm{nM}( \pm)-\left[{ }^{3} \mathrm{H}\right]-\mathrm{QNB}$. $K_{\mathrm{i}}$ values were calculated from $\mathrm{IC}_{50}$ data obtained by log-probit analysis of dose-response curves for inhibition of QNB binding, involving triplicate analysis of at least 4 concentrations of each test drug. Results are means \pm s.e. mean for number $(n)$ of separate experiments of this type indicated.

Our results are in contrast, however, to those of Strange et al. (1978) who were unable to detect saturable binding of $\left[{ }^{3} \mathrm{H}\right]-\mathrm{QNB}$ to intact neuroblastoma cells, although binding to membranes of the same cells could readily be measured.

However, there appeared to be substantial differences between slices and homogenates in the apparent affinity of $\left[{ }^{3} \mathrm{H}\right]-\mathrm{QNB}$ binding sites. In both striatal and hippocampal tissue $K_{\mathrm{d}}$ values in slices were approximately 8 times higher than those estimated in homogenates incubated in Krebs-bicarbonate solution. Furthermore, muscarinic agonists and antagonists were consistently less potent in inhibiting $\left[{ }^{3} \mathrm{H}\right]-\mathrm{QNB}$ binding in striatal slice preparations than in homogenates. Ward \& Young (1977) similarly reported that muscarinic drugs were less potent in inhibiting the binding of $\left[{ }^{3} \mathrm{H}\right]-\mathrm{PrBCM}$ to intact intestinal muscle strips than in cell free homogenate preparations. They suggested that differences could probably be explained, at least in part, in terms of accesslimitation factors for the penetration of the ligand and the test drugs to muscarinic sites in such intact tissue preparations.

Such factors could possibly account for the differences we have observed between slice and homo- genate preparations of brain tissue, but we do not feel this to be a very satisfactory explanation, for the following reasons:- (1) In the present studies, unlike those of Ward \& Young (1977) who measured the rate of binding of an irreversible ligand, we measured the binding of a reversible ligand under equilibrium conditions. (2) QNB is a lipophilic drug which penetrates readily into mammalian CNS even after systemic administration (Yamamura et al., 1974); thus, it seems unlikely that serious penetration barriers would exist in brain slices of the relatively small dimensions used in the present experiments. (3) The effective exposure of muscarinic sites in brain slices to the muscarinic ligand was confirmed by the finding that the maximum number of binding sites was similar in slices and homogenates.

It seems possible, therefore, that the differences in muscarinic binding obtained with intact brain slices and with homogenates may reflect real differences in the characteristics of such binding in intact tissue versus broken cell preparations.

M.R.H. was supported by a grant from the Scottish Rite Schizophrenia Research Program. R.F.G. is an MRC Scholar.

\section{References}

Birdsall, N.J.M., Burgen, A.S.V., Hulme, E.C. \& Wells, J.W. (1977). Muscarinic receptors: ionic perturbation of the binding properties. Br. J. Pharmac., 59, 503P.

Birdsall, N.J.M. \& Hulme, E.C. (1976). Biochemical studies on muscarinic acetylcholine receptors. J. Neurochem., 27, 7-16.

Burgen, A.S.V., Hiley, C.R. \& Young, J.M. (1974). The binding of $\left[{ }^{3} \mathrm{H}\right]$-propylbenzilylcholine mustard by longitudinal muscle strips from guinea pig small intestine. Br. J. Pharmac., 50, 145-151.

GlowinSKI, J. \& IVERSEN, L.L. (1966). Regional studies of the distribution of catecholamines in rat brain. I. The distribution of $\left[{ }^{3} \mathrm{H}\right]$-norepinephrine, $\left[{ }^{3} \mathrm{H}\right]$-dopamine and $\left[{ }^{3} \mathrm{H}\right]$-DOPA in various regions of the brain. $J$. Neurochem., 13, 655-669.

HANLEY, M.R. \& IVERSEN, L.L. (1978). Muscarinic cholinergic receptors in rat corpus striatum and regulation of guanosine cyclic 3',5'-monophosphate. Molec. Pharmac., 14, 246-255.

KLoog, Y. \& Sokolovsky, M. (1977). Muscarinic acetyl- 
choline receptors interactions: competition binding studies with agonists and antagonists. Brain Res., 134, 167-172.

MEYERHOFFER, A. (1972). Absolute configuration of 3-quinuclidinyl benzilate and the behavioural effect in the dog of the optical isomers. J. med. Chem., 15, 994-995.

Paton, W.D.M. \& Rang, H.P. (1965). Uptake of atropine and related drugs in relation to acetyl choline receptors. Proc. R. Soc., 163B, 1-45.

Rotter, A. Birdsall, N.J.M., Burgen, A.S.V., Field, P.M. \& Raisman, G. (1977). Axotomy causes loss of muscarinic receptors and synaptic contacts in the hypoglossal nucleus. Nature, Lond., 266, 732-734.

Strange, P.G., Birdsall, N.J.M. \& Burgen, A.S.V. (1978). Ligand binding properties of the muscarinic acetylcholine receptor in mouse neuroblastoma cells. Biochem. J.. 172, 495-501.
WARD, D. \& Young, J.N. (1977). Ligand binding to muscarinic receptors in intact longitudinal muscle strips from guinea-pig intestine. Br. J. Pharmac., 61, 189-197.

Yamamura, H.I. \& SNyder, S.H. (1974a). Muscarinic cholinergic binding in rat brain. P.N.A.S., 71, 1725-1729.

YamamuRa, H.I. \& SNYDER, S.H. (1974b). Muscarinic cholinergic receptor binding in the longitudinal muscle of the guinea-pig ileum with $\left[{ }^{3} \mathrm{H}\right]$-quinuclidinyl benzilate. Molec. Pharmac., 10, 861-867.

Yamamura, H.I., Kuhar, M.J. \& SNyder, S.H. (1974). In vivo identification of muscarinic cholinergic receptor binding in rat brain. Brain Res., 80, 170-176.

(Received June 26, 1978. Revised September 20, 1978.) 